\title{
5-Azacytidine induces micronuclei in and morphological transformation of Syrian hamster embryo fibroblasts in the absence of unscheduled DNA synthesis
}

\author{
H. Stopper, R. Pechan and D. Schiffmann \\ Institute of Pharmacology and Toxicology, University of Würzburg, W-8700 Würzburg, Germany \\ (Received 20 February 1992) \\ (Revision received 28 April 1992) \\ (Accepted 29 April 1992)
}

Keywords: 5-Azacytidine; Micronuclei; Kinetochores; Unscheduled DNA synthesis; Cell transformation

\section{Summary}

It is known that 5-azacytidine (5-AC) induces tumors in several organs of rats and mice. The mechanisms of these effects are still poorly understood although it is known that 5-AC can be incorporated into DNA. Furthermore, it can inhibit DNA methylation. The known data on its clastogenic and/or gene mutation-inducing potential are still controversial. Therefore, we have investigated the kinds of genotoxic effects caused by 5-AC in Syrian hamster embryo (SHE) fibroblasts. Three different endpoints (micronucleus formation, unscheduled DNA synthesis (UDS) and cell transformation) were assayed under similar conditions of metabolism and dose at target in this cell system. 5-AC induces morphological transformation of SHE cells, but not UDS. Therefore, 5-AC does not seem to cause repairable DNA lesions. Furthermore, our studies revealed that 5-AC is a potent inducer of micronuclei in the SHE system. Immunocytochemical analysis revealed that a certain percentage of these contain kinetochores indicating that 5-AC may induce both clastogenic events and numerical chromosome changes.

5-Azacytidine (5-AC) is an effective antineoplastic compound which has been used in the treatment of leukemia (Saiki et al., 1978). It induces tumors in several organs of rats (Carr et al., 1984) and mice in utero (Schmahl et al., 1985). $5-\mathrm{AC}$ is a cytidine analog containing a nitrogen atom at the 5 position instead of a carbon. Incor-

Correspondence: Dr. D. Schiffmann, Institute of Toxicology, University of Würzburg, Versbacher Str. 9, W-8700 Würzburg, Germany. poration of 5-AC into DNA results in the inhibition of DNA synthesis as well as DNA methylation. SOS-dependent mutagenic activity of 5-AC in Salmonella was shown by Schmuck et al. (1986). Mutagenic activity of 5-AC was observed in yeast by Zimmermann and Scheel (1984) and in Drosophila by Katz (1985). In the yeast system it also induced mitotic recombination but no chromosomal malsegregation.

In mammalian cells 5 -AC was not mutagenic in $\mathrm{C} 3 \mathrm{H} / 10 \mathrm{~T} 1 / 2$ and V79 cells at the ouabain and the hypoxanthine-guanine-phosphoribosyl- 
transferase (hgprt) loci (Landolph and Jones, 1982). It induced chromosome decondensation, sister-chromatid exchanges, and endoreduplications (Hori, 1983). 5-AC induced mutations in the thymidine kinase (tk) ${ }^{+/-}$human lymphoblastoid line TK6 at both the tk and the hgprt locus (Call et al., 1986). Interestingly, it was 5-10 times more effective at the tk locus than at the hgprt locus. It did not induce chromosomal aberrations due to clastogenic events in TK6 cells (Call et al., 1986). Amacher and Turner (1987) found 5-AC to be mutagenic at the tk locus in L5178Y mouse lymphoma cells. In another study (using the same cell system) by McGregor et al. (1989) 5-AC induced mutant colonies in the tk assay, but not the hgprt assay. Major perturbations of cell-cycle kinetics together with elevated rates of endomitosis and tetraploidization were found in human fibroblast-like cells from skin and amniotic fluid (Poot et al., 1990). A block in the $G_{2}$ phase of the cell cycle was also reported by Zatsepina et al. (1989) in pig kidney cells. 5-AC transformed cultures of $10 \mathrm{~T} 1 / 2$ and $\mathrm{M} 2$ mouse fibroblasts (Benedict et al., 1977; Harrison et al., 1983), primary rat tracheal epithelial cells (Walker and Nettesheim, 1986) and Balb/c-3T3 cells (Lubet et al., 1990).

Since the data on 5-AC-induced mutagenic or clastogenic effects are still controversial, we investigated the genotoxic effects caused by this agent in Syrian hamster embryo (SHE) fibroblasts. We assayed three different biological endpoints (micronucleus formation, unscheduled DNA synthesis (UDS), and cell transformation) under similar metabolic conditions and dose at target in this cell system.

\section{Materials and methods}

\section{Chemicals}

4-Nitroquinoline-1-oxide (4-NQO), hydroxyurea, Bisbenzimide 33258, 5-azacytidine and FITC-conjugated goat anti-human antibody were purchased from Sigma Chemical Co. (St. Louis, MO, USA). Dimethyl sulfoxide (DMSO) was acquired from Aldrich Company Europe (Nettetal, Germany). $\left[{ }^{3} \mathrm{H}\right]$ Thymidine (spec. act. $20 \mathrm{Ci} / \mathrm{mM}$ ) was obtained from Amersham Buchler Co. (Braunschweig, Germany), and CREST serum (anti-kinetochore-antibody) was purchased from Antibodies Incorporated (Davis, CA, USA).

\section{Cell culture}

SHE cells were established as described previously (Schiffmann et al., 1984). All experiments were performed with tertiary or quarternary cultures derived from 13-day-old Syrian hamster embryos. Cell cultures were grown in a humidified atmosphere with $12 \% \mathrm{CO}_{2}$ in air at $37^{\circ} \mathrm{C}$. The culture medium used was IBR-modified Dulbecco's reinforced medium (Grand Island Biological Co.), supplemented with $100 \mathrm{U} / \mathrm{ml}$ penicillin and $100 \mu \mathrm{g} / \mathrm{ml}$ streptomycin, $3.7 \mathrm{~g} / \mathrm{l} \mathrm{NaHCO}_{3}$ and $15 \%$ fetal calf serum (Gibco, Karlsruhe, Germany).

\section{UDS assay}

The UDS test was carried out according to the combined and modified procedures of Martin et al. (1978) and Lake et al. (1978). An arginine-deficient treatment in combination with short hydroxyurea treatment of the cells was applied to achieve a minimum background of replicative DNA synthesis (Schiffmann et al., 1983). Cells $\left(1.7 \times 10^{5}\right)$ were plated in triplicate on $30-\mathrm{mm}$ tissue-culture Petri dishes (Falcon Plastics, Oxnard, USA) in $2 \mathrm{ml}$ complete medium. After incubation for $48 \mathrm{~h}$ at $37^{\circ} \mathrm{C}$, the medium was replaced with arginine-free medium containing $2.5 \%$ dialyzed fetal calf serum (FCS); after $24 \mathrm{~h}$ this medium was again replaced by fresh arginine-free medium and incubation continued for a further $48 \mathrm{~h}$. At the end of this period this medium was again replaced by $1.2 \mathrm{ml}$ argininefree medium containing the indicated doses of test chemicals dissolved in DMSO (final concentration $0.1 \%),\left[{ }^{3} \mathrm{H}\right]$ thymidine $(10 \mu \mathrm{Ci} / \mathrm{ml})$ and hydroxyurea $(10 \mathrm{mM})$. All dishes were then incubated for $5 \mathrm{~h}$ at $37^{\circ} \mathrm{C}$ for DNA binding and repair. 4-NQO was used as positive control. UDS measurement was carried out according to a modified procedure previously published (Schiffmann et al., 1983). The treated cells were washed with 3 $\mathrm{ml}$ phosphate-buffered saline (PBS), and $1 \mathrm{ml}$ of $0.1 \%$ trypsin was added to remove the cells from the dishes; solubilization of the cells was achieved by subsequent addition of $1 \mathrm{ml}$ of $2 \%$ sodium dodecylsulfate. Ice-cold trichloroacetic acid $(2 \mathrm{ml}$, 
20\%) was then added to each sample and the resulting precipitate was collected on $24-\mathrm{mm}$ Whatman GF/C glass fiber filters; the precipitate was washed 4 times with $5 \mathrm{ml}$ of $5 \%$ ice-cold trichloroacetic acid and twice with absolute ethanol. The filters were then treated with $0.5 \mathrm{ml}$ tissue solubilizer (Protosol, New England $\mathrm{Nu}$ clear, Boston, MA, USA) for several hours at $50^{\circ} \mathrm{C}$ and after addition of $20 \mu \mathrm{l}$ of glacial acetic acid and toluene scintillator, the radioactivity was determined in a Packard scintillation counter, model 544.

\section{In vitro transformation assay}

For the transformation assay in SHE cells, a feeder layer of $2 \times 10^{4}$ lethally X-irradiated SHE cells ( $50 \mathrm{~Gy}$ ) was seeded in $3 \mathrm{ml}$ complete medium (IBR supplemented with $20 \%$ FCS) on $60-\mathrm{mm}$ Petri dishes (Falcon Plastics, Oxnard, USA). After $24 \mathrm{~h} \mathrm{150-200} \mathrm{target} \mathrm{cells} \mathrm{suspended} \mathrm{in} 1 \mathrm{ml}$ medium were added and, after a further $24 \mathrm{~h}$, various amounts of the test compounds dissolved in DMSO. The final concentration of DMSO in the medium did not exceed $0.1 \%(\mathrm{v} / \mathrm{v})$. Following a 48-h incubation period in a humidified incubator at $12 \% \mathrm{CO}_{2}$ and $37^{\circ} \mathrm{C}$, the medium was removed, the cells were washed with PBS and supplied with fresh culture medium. Eight days later, the cells were fixed with methanol, stained with $10 \%$ aqueous Giemsa and scored for cloning efficiency and morphological transformation according to the criteria (altered colony morphology consisting of criss-crossing and piling up of cells) described previously in detail by Berwald and Sachs (1965), DiPaolo et al. (1971) and Pienta (1980). Cell survival was determined in parallel by the conventional colony assay. After 10-12 days of incubation, fixation and staining, colonies with more than 50 cells were counted as survivors.

In vitro micronucleus assay and kinetochore analysis

SHE cells were plated in $35-\mathrm{mm}$ Petri dishes containing glass coverslips and grown to medium density. Then the cell culture medium was replaced by culture medium containing 5-AC (diluted in DMSO) or DMSO (final maximum concentration: $1 \% \mathrm{v} / \mathrm{v}$ ). Following an incubation period of $5 \mathrm{~h}$ the compound was removed by changing the medium. After $15 \mathrm{~h}$ (or different time points for time course) fixation was performed with methanol for at least $30 \mathrm{~min}$ at $-20^{\circ} \mathrm{C}$. The cells were then stained $(1 \mu \mathrm{g} / \mathrm{ml}$ Bisbenzimide 33258, $5 \mathrm{~min}$ ), washed 3 times with distilled water or PBS and mounted in Permafluor (Dianova) for microscopy. Micronuclei were determined at $1250 \times$ magnification. Kinetochore staining was achieved by incubating the fixed cell preparations (after rinsing with PBS) with CREST serum $(60 \mathrm{~min})$ in a humidified chamber at $37^{\circ} \mathrm{C}$. After rinsing with PBS again, the cells were incubated as before with FITCconjugated goat anti-human antibody (diluted $1: 100$ in PBS), rinsed again and counterstained with Bisbenzimide 33258 as described. Micronuclei were scored as such when up to three per cell were present. Cells with higher numbers of micronuclei were not registered. Mitotic index (cells in mitosis per 1000 cells) was determined in the same cell preparations that had been evaluated for the time course of micronucleus induction.

\section{Results}

\section{UDS assay}

The data obtained with 5-AC for UDS in SHE cells are given in Table 1. No UDS, i.e., no significant incorporation of $\left[{ }^{3} \mathrm{H}\right]$ thymidine exceeding that of background incorporation, was observed with 5-AC. At the highest dose tested $(2.0 \mu \mathrm{M})$ the level of replicative DNA synthesis was reduced to $84 \%$ of the control level indicating toxicity.

TABLE 1

UNSCHEDULED DNA SYNTHESIS (UDS) INDUCED BY 5-AC AND 4-NQO IN SHE CELLS

\begin{tabular}{llc}
\hline Compound & Concentration & cpm $/ 5 \times 10^{5}$ cells \\
\hline DMSO & $1 \%$ & $9870 \pm 683$ \\
4-NQO & $5.0 \mu \mathrm{M}$ & $58320 \pm 1422$ \\
$5-\mathrm{AC}$ & $0.2 \mu \mathrm{M}$ & $9853 \pm 648$ \\
& $0.4 \mu \mathrm{M}$ & $9829 \pm 615$ \\
& $1.0 \mu \mathrm{M}$ & $9141 \pm 606$ \\
& $2.0 \mu \mathrm{M}$ & $8323 \pm 567$ \\
\hline
\end{tabular}

Each data point represents the mean of three chemically treated cultures from one experiment. The experiments were repeated three times with consistent results. 
TABLE 2

MORPHOLOGICAL TRANSFORMATION OF SHE CELLS, INDUCED BY 5-AC AND 4-NQO

\begin{tabular}{|c|c|c|c|c|c|}
\hline \multirow[t]{2}{*}{$\begin{array}{l}\text { Com- } \\
\text { pound }\end{array}$} & \multirow[t]{2}{*}{$\begin{array}{l}\text { Concen- } \\
\text { tration }\end{array}$} & \multirow[t]{2}{*}{$\begin{array}{l}\text { Survival } \\
\text { (\%) }\end{array}$} & \multicolumn{2}{|c|}{$\begin{array}{l}\text { Transfor- } \\
\text { mation } \\
\text { frequency }\end{array}$} & \multirow[t]{2}{*}{$\begin{array}{l}\text { Signifi- } \\
\text { cance } \\
(\%)\end{array}$} \\
\hline & & & Ratio & $(\%)$ & \\
\hline DMSO & $0.1 \%$ & 100 & $0 / 896$ & 0 & - \\
\hline 4-NQO & $0.01 \mu \mathrm{M}$ & 91.2 & $3 / 817$ & 0.37 & $<10$ \\
\hline \multirow[t]{4}{*}{ 5-AC } & $0.2 \mu \mathrm{M}$ & 89.6 & $3 / 803$ & 0.37 & $<10$ \\
\hline & $0.4 \mu \mathrm{M}$ & 88.1 & $8 / 789$ & 1.01 & $<1$ \\
\hline & $1.0 \mu \mathrm{M}$ & 71.0 & $4 / 637$ & 0.63 & $<2$ \\
\hline & $2.0 \mu \mathrm{M}$ & 66.5 & $2 / 596$ & 0.34 & $<10$ \\
\hline
\end{tabular}

The transformation frequency is calculated from the ratio of transformed colonies to the number of surviving colonies. All experiments were repeated three times with consistent results. The present data represent the results of one experiment. All transformation frequencies were statistically significant as tested in the $x^{2}$ test.

\section{Morphological transformation}

Despite the inability to cause UDS in SHE cells, 5-AC induced morphological cell transformation (Table 2). The maximum transformation frequency was observed at a concentration of 0.4 $\mu \mathrm{M}$. At higher concentrations, a decline in cloning efficiency was noted, indicating that the compound was toxic to the cells (Table 2). This may also account for the lower transformation frequency observed at higher concentrations.

\section{Micronucleus assay}

5-AC induced micronuclei in SHE cells in a dose-dependent manner (Fig. 1). The time dependence of micronucleus formation was investigated (Fig. 2a). After removal of 5-AC the frequency of micronuclei rose above the control level and continued rising during the investigated expression time of $36 \mathrm{~h}$. Between 15 and $18 \mathrm{~h}$ an increased formation of micronuclei was observed. The time dependence is in contrast to that determined for diethylstilbestrol (DES) and 4-NQO, given in Fig. 2b. DES also induced micronuclei as early as $1 \mathrm{~h}$ after its removal (Schiffmann and De Boni, 1991). However, the micronucleus frequency was reduced after $18 \mathrm{~h}$ (duration of SHE cell cycle: $15-18 \mathrm{~h}$ ). In contrast, 4-NQO did not induce micronuclei before $18 \mathrm{~h}$ after removal of the compound.

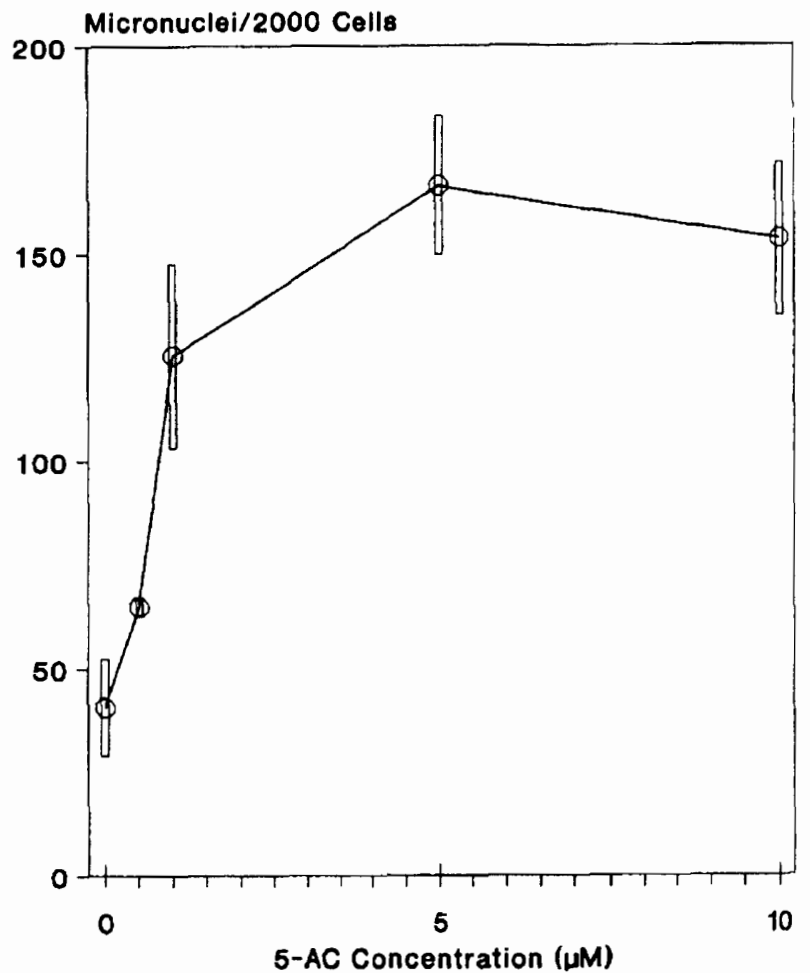

Fig. 1. Induction of micronucleus formation in SHE cells by 5-azacytidine. Data represent the mean of three treated cultures from one experiment. The experiments were repeated three times with consistent results.

The mitotic index (Fig. 2c) was markedly decreased compared to the control value during 5 - $\mathrm{AC}$ exposure, resulting in a low mitotic index after 5-AC removal. $6 \mathrm{~h}$ Iater a value similar to the untreated control was observed and a de-

TABLE 3

PRESENCE OF KINETOCHORES IN MICRONUCLEI (\%) IN SHE CELLS

\begin{tabular}{llll}
\hline Compound & Dose & $\%$ CRMN $^{+}$ & \\
\hline DMSO & $1 \% \mathrm{v} / \mathrm{v}$ & $23 \pm 7$ & (a) \\
5-AC & $10 \mu \mathrm{M}$ & $29 \pm 8$ & (a) \\
DES & $50 \mu \mathrm{M}$ & $85 \pm 3$ & (b) \\
4-NQO & $0.5 \mu \mathrm{M}$ & $6 \pm 2$ & (b) \\
\hline
\end{tabular}

(a) Each number represents the mean of three counts of 100 micronuclei (with standard deviation), evaluated for kinetochore presence.

(b) Data taken from Schiffmann and de Boni (1991) for comparison. These experiments were also perfomed with SHE cells, using the same procedure as described in this publication. 

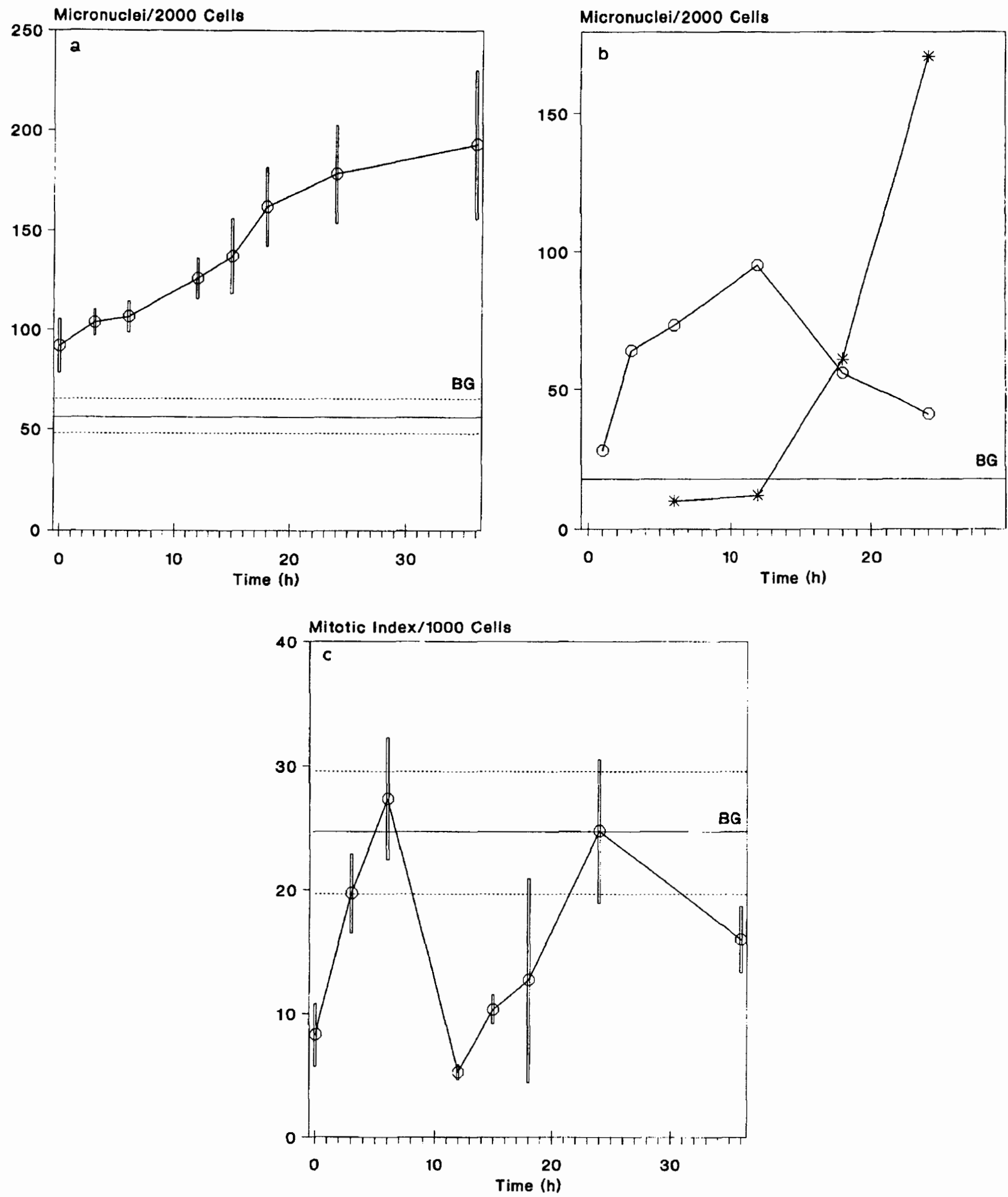

Fig. 2. (a) Time course of micronucleus induction by 5 -azacytidine $(10 \mu \mathrm{M})$ in SHE cells, starting at the time of 5-AC removal. Each data point represents the mean of three treated cultures from one experiment. The area marked 'BG' (background) indicates the mean of the spontaneous frequency. (b) Time course of micronucleus induction in SHE cells by 4-NQO (*, $0.5 \mu \mathrm{M})$ and DES $(0,50 \mu \mathrm{M})$. The line marked 'BG' indicates the spontaneous frequency. Data taken from Schiffmann and DeBoni (1991) and Schmuck et al. (1988). (c) Time course of changes in mitotic index after 5-azacytidine treatment $(10 \mu M)$ in SHE cells. Each data point represents the mean of three treated cultures from one experiment. The area marked ' $B G^{\prime}$ ' indicates the mean of the spontaneous frequency. 
crease occurred again after $12 \mathrm{~h}$. The following second increase coincided with the beginning of the second cell cycle after 5-AC removal.

Anti-kinetochore staining of micronuclei (Table 3) revealed that $29 \pm 8 \%$ of the 5 -AC-induced micronuclei reacted positively with CREST serum $\left(\mathrm{CRMN}^{+}\right)$. Control micronuclei (treated with DMSO, $1 \% \mathrm{v} / \mathrm{v})$ reacted in a similar way $(23 \pm$ $7 \% \mathrm{CRMN}^{+}$). The aneuploidy-inducing hormone DES induced $85 \pm 3 \% \mathrm{CRMN}^{+}$whereas the clastogen 4-NQO yielded $6 \pm 2 \% \mathrm{CRMN}^{+}$.

\section{Discussion}

In a previous study we compared the mutagenic activity of 5-AC in excision repair-deficient and -competent Salmonella strains (TA104 vs. TA2638) (Schmuck et al., 1986). We found only a small difference between the activities in the two strains. This result provides evidence that, in Salmonella, 5-AC produces only marginal base damage recognizable by excision repair. Our present negative UDS results suggest that 5-AC, in SHE cells, may also not cause excisable DNA damage.

5-AC induced morphological transformation of SHE cells with a high frequency (i.e., $>1 \%$ at 0.4 $\mu \mathrm{M})$. The mechanism of 5-AC-mediated cell transformation is still unknown. However, several observations support the notion that the hypomethylating effect of 5-AC is responsible for the induction of cell transformation: the results of Walker and Nettesheim (1986) show that the analog 6-azacytidine, which does not cause DNA hypomethylation, did not transform rat tracheal epithelial cells. Hsiao et al. (1985) and Harrison et al. (1983) have shown that 5-AC can neoplastically transform established cell lines, suggesting that changes in methylation occurring during later stages of transformation can result in the conversion of immortal cells to neoplastic cells. Further characterization of the process of malignant progression induced by 5-AC and related compounds, and molecular analysis of immortalized and neoplastic cells seem necessary.

5-AC-induced cell transformation occurred in a dose range similar to that where we found a dose-dependent increase in micronucleus frequency. However, the 5-AC-induced micronuclei seemed to be less intensely stained than those induced by a number of other compounds (e.g., DES, 4-NQO) indicating a structural change of chromatin. This effect may be related to the known 5-AC-mediated direct interference with chromosome condensation (Parrow et al., 1989). The early formation of 5-AC-mediated micronuclei suggests a development due to mitotic disturbances. Similar effects have been described for the aneuploidy-inducing agent DES (Schiffmann and De Boni, 1991), whereas clastogenic effects (e.g., induced by 4-NQO, Schmuck et al., 1988) give rise to micronuclei only after one additional cell cycle. A similar mechanism of 5-AC-mediated micronucleus induction may exist, which could be related either to the reported 5-AC-induced DNA instability (Sutherland et al., 1985) or to changes in chromosome condensation (Parrow et al., 1989) and elongation of the centromere region (Rattner and Lin, 1985, 1987). In fact, we observed increased numbers of cell pairs connected with narrow chromatid bridges especially shortly after 5-AC removal (unpublished observation).

Chromosomes showing such alterations may have an increased propensity to undergo disintegration (i.e., breakage). Alterations at the centromeric region may also affect kinetochore binding. After removal of 5-AC the mitotic index was markedly decreased which is in agreement with the findings of Zatsepina et al. (1989) and Poot et al. (1990) who reported an arrest in the $G_{2}$ phase of the cell cycle. The further increase of micronucleus frequency after completion of the first cycle could be a consequence of this arrest (partial synchronization). In combination with residual 5-AC inside the cells this may cause further development of micronuclei during the second mitosis. The relative frequency of $\mathrm{CRMN}^{-}$versus $\mathrm{CRMN}^{+}$further supports the notion that 5-AC induces chromosomal damage as well as the loss of whole chromosomes. Micronucleus induction caused by clastogenic effects leads to low percentages of $\mathrm{CRMN}^{+}$(6\% for 4-NQO), and micronucleus induction due to mitotic disturbances leads to high percentages of $\mathrm{CRMN}^{+}$(85\% for DES), which may result in the loss of whole chromosomes. According to the study of McGregor et al. (1989) 5-AC induced both small and 
large colonies in the L5178Y mouse lymphoma mutation assay. The production of small colonies in this assay has been associated with chromosomal lesions (Blazak et al., 1989). The different sensitivity in mutagenic response to $5-\mathrm{AC}$ at the hgprt versus the tk locus (Call et al., 1986; McGregor et al., 1989) may provide further support that 5-AC induces chromosomal lesions. Due to the absence of a homologous chromosome at the hgprt locus (sex-linked), a large lesion in that chromosome - inactivating flanking essential genes - would result in cell death.

In view of these results further investigations of the effects of 5-AC on mitosis and chromosome structure seem necessary. Therefore, studies are under way aiming at the identification of target components such as spindle fibers, kinetochores and centromeric DNA regions.

\section{Acknowledgements}

We thank Mrs. H. Bleifuss for excellent technical assistance. This work was supported by the Hauptverband der Gewerblichen Berufsgenossenschaften, W-5205 St Augustin, Germany.

\section{References}

Amacher, D., and G. Turner (1987) The mutagenicity of 5-azacytidine and other inhibitors of replicative DNA synthesis in the L5178Y mouse lymphoma cell, Mutation Res., 176, 123-131.

Benedict, W.F., A. Banerjee, A. Gardner and P.A. Jones (1977) Induction of morphological transformation in mouse $\mathrm{C} 3 \mathrm{H} / 10 \mathrm{~T} 1 / 2$ clone 8 cells and chromosomal damage in hamster $\mathrm{A}(\mathrm{T} 1) \mathrm{C} 1-3$ cells by cancer chemotherapeutic agents, Cancer Res., 37, 2202-2208.

Berwald, Y., and L. Sachs (1965) In vitro transformation of normal cells to tumor cells by carcinogenic hydrocarbons, J. Natl. Cancer Inst., 35, 641-657.

Blazak, W., F. Los, C. Rudd and W. Caspary (1989) Chromosome analysis of small and large L5178Y mouse lymphoma cell colonies: comparison of trifluorothymidine-resistant and unselected cell colonies from mutagen-treated and control cultures, Mutation Res., 224, 197-208.

Call, K.M., J.C. Jensen, H.L. Liber and W.G. Thilly (1986) Studies of mutagenicity and clastogenicity of 5-azacytidine in human lymphoblasts and Salmonella typhimurium, Mutation Res., 160, 249-257.

Carr, B.I., J. Garrett Reilly, S.S. Smith, C. Winberg and A. Riggs (1984) The tumorigenicity of 5-azacytidine in the male Fisher rat, Carcinogenesis, 5, 1583-1590.
DiPaolo, J.A., R.L. Nelson and P.J. Donovan (1971) Morphological, oncogenic and karyological characterization of Syrian hamster embryo cells transformed in vitro by carcinogenic polycyclic hydrocarbons, Cancer Res., 31, 1118-1127.

Harrison, J.J., A. Anisowicz, I.K. Gadi, M. Raffeld and R. Sager (1983) Azacytidine-induced tumorigenesis of CHEF/18 cells: correlated DNA methylation and chromosome changes, Proc. Natl. Acad. Sci. (U.S.A.), 80, $6606-6610$.

Hori, T.A. (1983) Induction of chromosome decondensation, sister-chromatid exchanges and endoreduplications by 5azacytidine, an inhibitor of DNA methylation, Mutation Res., 121, 47-52.

Hsiao, W.L.W., S. Gattoni-Celli and I.B. Weinstein (1985) Effects of 5-azacytidine on the progressive nature of cell transformation, Mol. Cell. Biol., 5, 1800-1803.

Katz, A.J. (1985) Genotoxicity of 5-azacytidine in somatic cells of Drosophila, Mutation Res., 143, 195-199.

Lake, R.S., M.L. Kropko, M. Pezzutti, R.H. Shoemaker and H.J. Igel (1978) Chemical induction of unscheduled DNA synthesis in human skin epithelial cell cultures, Cancer Res., 38, 2091-2098.

Landolph, J.R., and P.A. Jones (1982) Mutagenicity of 5azacytidine and related nucleosides in $\mathrm{C} 3 \mathrm{H} / 10 \mathrm{~T} 1 / 2$ clone 8 and V79 cells, Cancer Res., 42, 817-832.

Lubet, R.A., R.E. Kouri, R.A. Curren, D.L. Putman and L.M. Schechtman (1990) lnduction of mutagenesis and transformation in Balb/c-3T3 clone A31-1 cells by diverse chemical carcinogens, Environ. Mol. Mutagen., 16, 13-20.

Martin, C.N., A.C. McDermid and R.C. Garner (1978) Testing of known carcinogens and noncarcinogens for their ability to induce unscheduled DNA synthesis in HeLa cells, Cancer Res., 38, 2621-2627.

McGregor, D.B., A.G. Brown, P. Cattanach, W. Sheperd, C. Riach, D.S. Daston and W.J. Caspary (1989) TFT and 6TG resistance of mouse lymphoma cells to analogs of azacytidine, Carcinogenesis, 10, 2003-2008.

Parrow, V.C., P. Alestrom and K.M. Gautvick (1989) 5Azacytidine induced alterations in $\mathrm{GH} 12 \mathrm{Cl}$ cells: effect on cellular morphology, chromatin stucture, DNA and protein synthesis, J. Cell. Sci., 93, 533-543.

Pienta, R.J. (1980) Transformation of Syrian hamster embryo cells by diverse chemicals and correlation with their reported carcinogenic and mutagenic activities, in: F.J. de Serres and A. Hollaender (Eds.), Chemical Mutagens: Principles and Methods for their Detection, Vol. 6, Plenum, New York, pp. 175-202.

Poot, M., J. Koehler, P.S. Rabinovitch, H. Hoehn and J.H. Priest (1990) Cell kinetic disturbances induced by treatment of human diploid fibroblasts with 5-azacytidine indicate a major role for DNA methylation in the regulation of the chromosome cycle, Hum. Genet., 84, 258-262.

Rattner, J.B., and C.C. Lin (1985) Centromere organization in chromosomes of the mouse, Chromosoma, 92, 325-329.

Rattner, J.B., and C.C. Lin (1987) The higher order structure of the centromere, Genome, 29, 588-593.

Saiki, J.H., K.B. McCredie, T.J. Vietti, J.S. Hewlett, F.S. Morrison, J.J. Costanzi, W.J. Stuckey, J. Whitecar and B. 
Hoogstraten (1978) 5-Azacytidine in acute leukemia, Cancer, 42, 2111-2114.

Schiffmann, D., and U. De Boni (1991) Dislocation of chromatin elements in prophase induced by diethylstilbestrol: a novel mechanism by which micronuclei can arise, Mutation Res., 246, 113-122.

Schiffmann, D., E. Eder, T. Neudecker and D. Henschler (1983) Induction of unscheduled DNA synthesis in HeLa cells by allylic compounds, Cancer Lett., 20, 263-269.

Schiffmann, D., D. Reichert and D. Henschler (1984) Induction of morphological transformation and unscheduled DNA synthesis in Syrian hamster embryo fibroblasts by hexachlorobutadiene and its putative metabolite pentachlorobutenoic acid, Cancer Lett., 23, 297-305.

Schmahl, W., E. Geber and W. Lehmacher (1985) Diaplacental carcinogenic effects of 5 -azacytidine in NMRI-mice, Cancer Lett., 27, 81-90.

Schmuck, G., R. Pechan, D. Wild, D. Schiffmann and D. Henschler (1986) SOS-dependent mutagenic activity of 5-azacytidine in Salmonella, Mutation Res., 175, 205-208.
Schmuck, G., G. Lieb, D. Wild, D. Schiffmann and D. Henschler (1988) Characterization of an in vitro micronucleus assay with Syrian hamster embryo fibroblasts, Mutation Res., 203, 397-404.

Sutherland G., M. Parslow and E. Baker (1985) New classes of common fragile sites induced by 5 -azacytidine and bromodeoxyuridine, Hum. Genet., 69, 233-237.

Walker, C., and P. Nettesheim (1986) In vitro transformation of primary rat tracheal epithelial cells by 5 -azacytidine, Cancer Res., 46, 6433-6437.

Zatsepina, O.V., V.O. Airapetian and G.I. Kir'ianov (1989) The effect of 5-azacytidine on the cell cycle and chromosome structure in cell cultures of swine embryonal kidney tissue, Mol. Biol. Mosk., 23, 772-782 (in Russian).

Zimmermann, F.K., and I. Scheel (1984) Genetic effects of 5 -azacytidine in Saccharomyces cerevisiae, Mutation Res., 139, 21-24.

Communicated by F.H. Sobels 